\title{
Sustainability indicators of a naturally ventilated photovoltaic façade system
}

Article

Accepted Version

Creative Commons: Attribution-Noncommercial-No Derivative Works 4.0

Garraín, D., Herrera, I., Rodríguez-Serrano, I., Lechón, Y., Hepbasli, A., Araz, M., Biyik, E., Yao, R., Shahrestani, M., Essah, E., Shao, L., Rico, E., Lechón, J. L. and Oliveira, A. C. (2020) Sustainability indicators of a naturally ventilated photovoltaic façade system. Journal of Cleaner Production, 266. 121946. ISSN 0959-6526 doi:

https://doi.org/10.1016/j.jclepro.2020.121946 Available at https://centaur.reading.ac.uk/90714/

It is advisable to refer to the publisher's version if you intend to cite from the work. See Guidance on citing.

Published version at: https://doi.org/10.1016/j.jclepro.2020.121946

To link to this article DOI: http://dx.doi.org/10.1016/j.jclepro.2020.121946

Publisher: Elsevier

All outputs in CentAUR are protected by Intellectual Property Rights law, including copyright law. Copyright and IPR is retained by the creators or other copyright holders. Terms and conditions for use of this material are defined in the End User Agreement. 


\section{CentAUR}

Central Archive at the University of Reading

Reading's research outputs online 


\section{Sustainability indicators of a naturally ventilated photovoltaic}

\section{façade system}

Daniel Garraín ${ }^{1 *}$, Israel Herrera ${ }^{1}$, Irene Rodríguez-Serrano ${ }^{1}$, Yolanda Lechón ${ }^{1}$, Arif Hepbasli $^{2}$, Mustafa Araz ${ }^{2}$, Emrah Biyik ${ }^{2}$, Rumming $\mathrm{Yao}^{3}$, Mehdi Shahrestani ${ }^{3}$, Emmanuel Essah ${ }^{3}, \mathrm{Li} \mathrm{Shao}^{3}$, Elena Rico ${ }^{4}$, Juan Luis Lechón ${ }^{4}$, Armando C. Oliveira $^{5}$ ${ }^{1}$ CIEMAT, Energy Department, Energy Systems Analysis Unit, Av Complutense 40, E28040 Madrid, Spain.

${ }^{2}$ Department of Energy Systems Engineering, Faculty of Engineering, Yasar University, Izmir 35100, Turkey.

${ }^{3}$ School of Construction Management and Engineering, University of Reading, UK.

${ }^{4}$ ONYX Solar, Spain

${ }^{5}$ Mechanical Engineering Department - FEUP, University of Porto, Portugal.

*Corresponding author: daniel.garrain@ciemat.es

\section{Abstract:}

Building Integrated Photovoltaic (BIPV) systems have been increasingly used as a means to generate electricity on-site, and their diffusion will increase in the near future. The objective of this article is to carry out a sustainability assessment of a BIPV system installed in Turkey regarding the three pillars: environmental, economic and social potential impact, in order to develop different indicators. For the socioeconomic analysis, a Multiregional Input-Output (MRIO) method was used to estimate production of goods and services, value added creation and employment opportunities. For the environmental evaluation, an Environmental Footprint (EF) analysis was performed. The levelized electricity costs and the greenhouse gas emissions abatement costs were also calculated. Results showed that the socioeconomic effects are relevant, although only a $23 \%$ of these effects remain in Turkey. The environmental profile is also good in terms of climate 
change impacts, showing substantial reductions in greenhouse gas emissions compared to fossil fuel alternatives for electricity generation. Regarding the life cycle stages of the technology, the highest environmental impacts are produced in the PV manufacturing processes. The electricity produced is still more costly than fossil-based technologies and in the highest range of PV technologies, but greenhouse gases abatement costs are not so high when compared to other references.

Keywords: Building Integrated Photovoltaic (BIPV), sustainability, Multi-Regional Input-Output (MRIO), Environmental Footprint (EF), Life Cycle Assessment (LCA).

\section{Highlights}

- The socioeconomic effects of the deployment of a Building Integrated Photovoltaic (BIPV) system are relevant with a high multiplier effect, but only $23 \%$ of these effects remain in Turkey.

- Substantial reductions in greenhouse gas emissions compared to fossil fuel alternatives for electricity generation can be obtained.

- The highest environmental impacts are due to the Photovoltaic (PV) manufacturing processes.

- The electricity produced is still more costly than fossil-based technologies and in the highest range of PV technologies, but greenhouse gases abatement costs are not so high when compared to other references. 


\section{Introduction}

\subsection{BIPV systems and the REELCOOP project}

Building Integrated Photovoltaic (BIPV) systems have been increasingly used (Agathokleous et al., 2018; Curtius, 2018) as a means to generate electricity on-site, and their diffusion will increase in the near future, taking into account the EU regulation on nearly net zero energy buildings (nZEB), called Energy Performance Building Directive (EPBD) (EC, 2010). This concept considers a building that has a very high energy performance, that is to say, that energy must be covered basically from renewable sources produced on-site or nearby, usually requiring on-site electricity generation and sale to the electrical grid (Tripathy et al., 2017).

Photovoltaic (PV) and solar thermal (ST) systems, together with biomass or geothermal sources, are the most common renewable energy sources used in buildings. Due to their easy integration into façades and roofs, BIPV shows a great potential to be used as renewable energy system (Silva et al., 2016). One of the limitations of this solution may be the incremental cost of panels, but it could be reduced by avoiding the cost of conventional construction materials; then BIPVs often have a lower price than PV systems (Debbarma et al., 2017). Nevertheless, BIPVs still represent a small share of the PV market. Then, efforts for developing and breaking into the market should be done in order to satisfy the potential demand of the building sector (Biyik et al., 2017). A complete study about advantages and limitations of BIPV systems can be consulted in Baljit et al. (Baljit et al., 2016).

It was within this framework that the REELCOOP (REnewable ELectricity COOPeration) project came up. It was an EU-funded seventh Framework Programme (FP7) Research and Development (R\&D) project aiming at developing different renewable electricity generation technologies, while at the same time strengthening 
research cooperation between the European Union (EU) and Mediterranean Partner Countries / Middle East and North Africa (MPC/MENA) countries. Within its framework five renewable energy areas were addressed: PV, ST, concentrated solar power (CSP), bioenergy and grid integration. The overall objective of REELCOOP was to study and develop both distributed and centralised electricity generation systems. This is in accordance with the EU SET-Plan approach of developing a European electricity grid able to integrate renewable and decentralised energy sources. Major objectives were the design, installation and testing of three different prototypes, addressing the different technologies. This study is focused on one of them: a novel BIPV prototype system which was installed in Turkey and tested for about two years.

The performance evaluation of the BIPV prototype and the enhancement of the electrical efficiency have been deeply studied and previously published in (Costanzo et al., 2018)(Araz et al., 2017; Biyik et al., 2017) .

\subsection{Objective: Sustainability assessment}

The objective of this article is to carry out a sustainability assessment regarding the three main pillars: environmental, economic and social potential impacts. Most of the published scientific manuscripts related to the sustainability aspects of renewable energies usually analyse economic, socioeconomic or environmental impacts separately. Ludin et al. (Ludin et al., 2018) published a review of Life Cycle Assessments (LCA) of PV technologies considering three main impacts: Climate Change (CC), Cumulative Energy Demand (CED) and Energy Payback Time (EPBT). Other studies, such as Tsang et al. (Tsang et al., 2016) or Jayathissa et al. (Jayathissa et al., 2016), have studied the opportunities and the environmental impact of organic PV modules or some environmental impact categories in an LCA of a BIPV, respectively. Particular LCAs of different types of PV have been carried out by Kim el al. (Kim et al., 2014) in Malaysia, 
Kannan et al. (Kannan et al., 2006) in Singapore, Hong et al. (Hong et al., 2016) in China, Sierra et al. (Sierra et al., 2019) in Colombia, Menoufi et al. (Menoufi et al., 2013) in Spain, and Lamnatou et al. (Lamnatou et al., 2016) in several places of Europe. The main relevant results were the reduction of $\mathrm{CC}$ potential when they are compared to conventional energy sources, as expected. Regarding te economic pillar, Gholami et al. (Gholami et al., 2019) published an article including a holistic review of five case studies around the world. Moreover, two interesting studies about end-of-life (EoL) stage of PV could be highlighted: Goe \& Gaustad (Goe and Gaustad, 2016) studied the influence of the recycling process of PV modules in global warming potential (GWP) credits for decreasing impacts in United States (US), while Latunussa et al. (Latunussa et al., 2016) published an LCA about an innovative process for recycling these panels, including a complete state-of-the-art on EoL techniques.

Sustainability assessments considering the above three impacts have gradually increased; at the same time that guidelines related to sustainability assessment methods are being created. Cucchiella et al. (Cucchiella et al., 2015) performed a very interesting work about BIPV systems sustainability, but considering only five economical and environmental indicators. An outstanding study from Corona et al. (Corona et al., 2016) published both the environmental and socioeconomic effects of a CSP plant located in Spain. A similar complete sustainability study for BIPV systems have not yet been published. This work trys to fill this gap and perform a complete sustainability assessment of a BIPV system that al showcasing all the potential environmental social and economic impacts of this technology. In this work, and based on this approach, two recognized methodologies have been applied to estimate the environmental and socioeconomic effects: i) Multiregional Input-Output Analysis (MRIO) in order to calculate the direct and indirect socioeconomic effects in terms of production of goods and services (G\&S), added value (AV) creation 
and employment; and ii) Environmental Footprint (EF) through an LCA approach in order to calculate the potential environmental impact in different impact categories. Then, this study contributes to the improvement of the global sustainability assessment of this technology in the literature by introducingsocio economic indicators and a more completed environmental assessment thanks to the use of the European Commission recommended methodology to calculate the EF.

The sustainability analysis developed in this work helps to identify and assess the opportunities for wide-scale solution-oriented application of photovoltaic power electricity generation in an urban environment, by means of the presented sustainability indicators.

\section{Description of the analysed system}

The BIPV system was installed on the façade of a building (Building Y) at Yasar University (YU) campus, İzmir, Turkey. The layout and a 3D-model of the building are illustrated in figure 1 , where the chosen façade is shown in a red rectangle. As can be seen, the façade is facing towards southeast.

\section{[figure 1]}

A picture of the BIPV system is given in figure 2 while its schematic representation is shown in figure 3 . This system is named as a ventilated façade and it comprises a total of forty-eight crystalline silicon (c-Si) modules (see table 1 for the technical specifications), in four rows and twelve columns. The gap between the modules and the wall is kept at $150 \mathrm{~mm}$, causing an increase in the efficiency of the system thanks to the natural ventilation effect. Each BIPV module used in the system has a power of $155 \mathrm{~W}_{\mathrm{p}}$, making a total capacity of $7.44 \mathrm{~kW}_{\mathrm{p}}$ for the system. Due to the transparency of the modules, the total cell area of the system is $40.10 \mathrm{~m}^{2}$ while the total BIPV area is $57.60 \mathrm{~m}^{2}$. 
[figure 2]

[figure 3]

[table 1]

It is clear from the single line diagram given in figure 4; a $7 \mathrm{~kW}$ three-phase inverter with two independent Maximum Power Point Tracking (MPPT) inputs was selected for the system. Other necessary units such as DC/AC protections were also installed at the inlet and exit of the inverter. The inverter converts the DC input to AC and feeds the building grid with the generated electricity. Electrical measurements are also made with the inverter at five-minutes intervals, thanks to the integrated FTP (File Transfer Protocol) server located inside.

\section{[figure 4]}

There is also other measurement equipment installed at necessary locations for experimental analyses. The locations of these instruments can be seen in figure 5. Air temperatures between the wall and the modules are measured at sixteen different locations (shown in red circles) while the PV surface temperatures are measured on twenty-four points (shown in black circles). On the other hand, the air velocity behind the modules (shown in green circles) and solar irradiation values on the façade (shown in yellow circles) are measured at six locations using thermo-anemometers and pyranometers. These pyranometers are installed on the corners and at midpoints of the façade to be able to take shading effects into account. There is also another pyranometer at the top of the building, which measures global and diffuse irradiations on horizontal. Also, a weatherstation is installed just next to the upper string to measure wind velocity and direction, air temperature and humidity. Some pictures of these devices are given in figure 6 . All these 
instruments are connected to a sixty-channel data-logger with internet connection measurements and all data are continuously recorded on this data-logger.

[figure 5]

[figure 6]

\section{Methodologies}

\subsection{Socioeconomic assessment}

The Input-Output (IO) methodology allows estimating the total economic stimulation produced in the different economic sectors from an increase in the demand of G\&S when an investment in a technology/project is produced. The monetary flows existing among economic sectors are analysed throughout the use of Input-Output Tables (IOTs) where columns define the economic value of products or services that a sector needs from other sectors (inputs) to obtain the whole production; whereas rows display the distribution in economic figures of the production of one sector over the rest of the sectors (outputs) (Wiedmann et al., 2007). When various regions or countries around the world are considered, the change in the demand of G\&S produced in a country from the investment done in another country can be estimated using multiregional input-output (MRIO) tables (Miller and Blair, 2009). From the MRIO tables, the technical coefficient matrix can be obtained, which represents the amount of G\&S expressed in monetary terms that a sector needs from the other sectors to obtain one monetary unit of production (Caldés et al., 2009; ten Raa, 2006).

Total effects include the estimation of direct and indirect effects. On the one hand, direct effects are the required G\&S needed in the investment and operational phases of the project. On the other hand, indirect effects are the economic stimulation produced by the economic sectors which provide G\&S to the economic sectors directly involved. The total 
economic stimulation produced from the direct effects is called the multiplier effect (Caldés et al., 2009).

Employment generation is also estimated with the IO method by means of the addition of a socioeconomic vector expressing the number of employees created in a specific economic sector and year by monetary unit produced.

3.2. Levelized Cost of Electricity (LCOE) and greenhouse gas emissions (GHG) abatement costs calculation

Other economic indicators have been calculated, such as the Levelized Cost of Electricity (LCOE), which consists on the aggregation of all costs of the plant life cycle divided by the electricity generated along the plant life; and the greenhouse gases (GHG) abatement cost, once the LCOE value was obtained and also the results of global warming emissions were known from the environmental analysis.

LCOE has been calculated using Equation 1, taking into account 30 years of operation and a $4 \%$ discount rate. Moreover, a rate of $0.6 \%$ of PV modules degradation has been accounted for the calculation of the annual electricity generated.

$$
\mathrm{LCOE}=\frac{\sum_{\mathrm{t}=1}^{\mathrm{n}} \frac{\mathrm{I}_{\mathrm{t}}+\mathrm{M}_{\mathrm{t}}+\mathrm{F}_{\mathrm{t}}}{(1+\mathrm{r})^{\mathrm{t}}}}{\sum_{\mathrm{t}=1}^{\mathrm{n}} \frac{\mathrm{E}_{\mathrm{t}}}{(1+\mathrm{r})^{\mathrm{t}}}}
$$

where $I_{t}$ is the investment cost, $M_{t}$ is the annual operational and maintenance cost, $F_{t}$ is the fuel cost, $E_{t}$ is the annual electrical generation.

GHG abatement costs are the costs of reducing GHG emissions and were calculated using the following expression:

$$
\text { GHG abatement costs }=\frac{\text { Difference in LCOE vs coal }\left(\frac{E U R}{\mathrm{kWh}}\right)}{\text { Difference in GHG emissions vs coal }\left(\frac{\mathrm{tCO2eq}}{\mathrm{kWh}}\right)}
$$

The following assumptions from relevant and authoritative sources were considered: 
- LCOE of coal electricity: 0.080 US\$2015/kWh (IEA, 2015).

- Life cycle GHG emissions of coal electricity: 1.00 kg CO $2 \mathrm{eq} / \mathrm{kWh}$ (NREL, 2018).

\subsection{Environmental assessment}

The Life Cycle Assessment (LCA) methodology is a tool for measuring the potential environmental impact of a product, process or system, throughout its life cycle. It is based on the collection and analysis of the inputs and outputs of the system to obtain results that show the potential environmental impacts. Therefore, it is an objective process that allows evaluating the environmental burdens associated with a product, process or activity, identifying and quantifying both the use of matter and energy and emissions to the environment, to determine the impact of that use of resources and these emissions and to evaluate and implement environmental improvement strategies (ISO, 2006a, 2006b).

Given the diversity of existing methodological approaches, the European Commission (EC) tried to unify them to develop a method of quantifying and characterizing environmental impacts, called Environmental Footprint (EF). The focus of the LCA and the EF and the phases of the assessment are the same, even the factors and the elaboration process. The main difference is the already defined impact categories in EF. The purpose of the EF impact assessment is to collect the inventory data according to their contributions to each EF impact category. Then, the basis for interpretation of the EF results relatively to the goals of the study is provided. The EF impact assessment methods use models for quantifying the causal relationships between the material/energy inputs and emissions associated with the product life cycle and each EF impact category considered. Each category hence refers to a certain stand-alone EF impact assessment model. The selected categories are the following, as the ILCD midpoint+ characterisation method (EC, 2018): climate change [CC], ozone depletion [OD], human toxicity (cancer $[\mathrm{HTc}]$ and non-cancer effects $[\mathrm{HTnc}])$, particulate matter $[\mathrm{PM}]$, ionizing radiation human 
health [IRhh], ionizing radiation ecosystems (interim) [IRe], photochemical ozone formation $[\mathrm{POF}]$, acidification $[\mathrm{AC}]$, eutrophication (terrestrial [EUt], freshwater [EUf] and marine [EUm]), freshwater ecotoxicity [FEC], land use [LU], water resource depletion [WRD], and mineral, fossil and renewable resource depletion [MFR] (Benini et al., 2014; EC, 2013; Manfredi et al., 2012).

\section{Data and assumptions}

\subsection{Socioeconomic assessment}

The main database used in this work has been the World Input-Output Database (WIOD), resulted from a European Commission (EC) funded project within the 7th Framework Programme (WIOD, 2017a).

\subsubsection{Cost data}

Cost data of both investment and Operation and Maintenance $(\mathrm{O} \& \mathrm{M})$ phases of the BIPV system are shown in tables 2 and 3. Investment cost data were provided by ONYX, a Spanish company where the PV panel and structure were developed and by the University of Yasar. The addition of the whole costs determined the total costs of the system (as well as the resulting LCOE), that will be displayed according to the corresponding economic sectors and countries.

a. Investment costs

Table 1 shows disaggregated investment costs for the BIPV systems well as the corresponding manufacturing country.

[table 2]

b. Operation and Maintenance (O\&M) costs

O\&M costs and assumptions are displayed in Table 3. Data were provided by Onyx and a $4 \%$ discount rate has been applied in order to obtain the Net Present Value (NPV) of these costs along the life time of the prototype. A degradation rate of the modules of $0.6 \%$ 
has been considered in order to compute the total production of electricity along the life time of the prototype.

[table 3]

\subsubsection{Demand vector}

a. Investment and Operation and Maintenance demand of Goods and Services $(\mathrm{G} \& S)$

Once all costs had been accounted for, they were assigned to the different economic sectors and countries according to the United Nations Statistics Division (UNSD, 2017). This allowed constructing the demand vector, which corresponds to the direct effects, which will later be used to calculate the indirect effects. Table 4 shows the final demand vector, which has the total investment and operational costs assigned to the corresponding economic sectors of each country. This vector excludes personnel costs, which will later be used to calculate induced effects. These costs are expressed in $\$ 2011$, since this is the monetary unit of the MRIO tables used.

[table 4]

b. Induced demand

Salaries received by employees were reinvested in the economy as an induced an additional demand. Personnel costs related to the manufacturing phase amounted to $2434.78 €_{2018}$. Considering that the main manufacturing countries were Taiwan and Spain, the total personnel costs were allocated according to the percentage of components manufactured by both countries: Taiwan $48 \%$ and Spain $52 \%$.

Part of the salaries was spent in social security and another part was saved. Therefore, the cost related to social security and related costs and the part of the wages that were saved in both countries were subtracted to those personnel costs. In this sense, from the direct personnel costs, the directly induced demand amounts to $1948.94 €_{2018}$, from which 
$1013.45 €_{2018}$ corresponds to Spain and $935.49 €_{2018}$ corresponds to Taiwan. Finally, these costs were distributed along the different economic sectors of each country according to the 'Final consumption expenditure by households' of each country, extracted from the WIOD database (WIOD, 2017b).

Indirect induced effects were calculated in the same way, taking into account the employment results from the IO calculations. The wage vector was constructed taking into account the 'compensation of employees' socioeconomic data from 2011 of the WIOD database (WIOD, 2017b) and the total output of each economic sector in the same year. Then, the vector was multiplied by the total production of G\&S from the IO results and the total wages resulted in each country were distributed in the different economic sectors regarding the household expense distribution of each country among their economic sectors (WIOD, 2017b).

c. Total demand of Goods and Services (G\&S)

Table 5 shows the final demand of G\&S including the direct induced demand.

[table 5]

\subsection{Environmental assessment}

\subsubsection{Goal and scope}

The goal of this assessment was to calculate the EF, where the unit of analysis is the production of $1 \mathrm{kWh}$ of electricity output from the prototype. A lifespan of 30 years has been considered, being this the average value of this type of upscaled infrastructures (Ludin et al., 2018). The system boundary comprises all relevant processes from the raw material extraction, production and manufacturing until the stage of end-of-life of the products with the transportation stages included. The different stages considered have been categorized in the processes of manufacturing of the components: PV panel, junction box, electrical installation, mechanical installation (named 'sistema vidrio') and the 
balance of the system (BoS) of the components -which comprise every component essential to the electrical, thermal or aesthetic integrity of the array, forming part of the overarching power generating facility located in the building. An end-of-life stage of waste disposal in landfill has been also considered, including the transportation stage. No recycling of the PV components has been considered at this point due to uncertainty and lack of data about recycling processes.

\subsubsection{Life Cycle Inventory (LCI)}

The considerations and assumptions, such as the energy coefficients and the service periods assigned for the BIPV system, the installations and the operation stages, before compiling inventory data, are detailed in table 6.

\section{[table 6]}

The total electrical production in order to calculate the reference of the analysis unit has been obtained from system measured data: $6000 \mathrm{kWh} /$ year with a degradation rate of $0.6 \%$ per year. The total electricity has been calculated to be $170 \mathrm{MWh}$ in 30 years.

Table 7 shows all components considered in the BIPV prototype. Data were provided by ONYX and YU.

\section{[table 7]}

Appendix A provides de LCI details for all these components.

\section{Results and discussion}

\subsection{Socioeconomic assessment}

\subsubsection{Production of $G \& S$ and added value $(A V)$ creation}

Once the demand vector is constructed, it can be multiplied by the Leontief Inverse Matrix (Leontief, 1986) to obtain the indirect effects, estimating the total demand of G\&S of each phase. It is also possible to calculate the multiplier effect, which indicates the global 
economic stimulation produced by each direct monetary unit invested in the project. Table 8 shows the total production of G\&S and value added creation in each project phase. Figure 7 shows the contribution of direct, indirect and induced effects in the production of G\&S and AV creation. The multiplier effect was estimated at 2.75.

\section{[table 7]}

[figure 7]

\subsubsection{Employment effects}

Direct employees were estimated from the personnel cost data. Taking into account the days needed for manufacturing the modules, the total personnel cost given and the average daily wages of the corresponding countries, the Full Time Equivalent (FTE) employees have been calculated for Spain and Taiwan. Table 9 shows the assumptions considered and the resulting direct FTE for each country.

[table 9]

Indirect FTE employees are calculated by multiplying the employment vector constructed with WIOD data by the total economic effects obtained in the MRIO assessment. The employment vector is calculated by dividing the 'people engaged' socioeconomic account data available for 2011 in each economic sector and country (WIOD, 2017b) by the total output obtained by each economic sector and country in the same year from the MRIO. Table 10 shows the total direct and indirect FTE effects in the investment and O\&M phases.

[table 10]

\subsubsection{Contribution of the main economic sectors}

Finally, the main economic sectors responsible for the largest shares of the three types of socioeconomic effects analysed are displayed in Table 11. 
[table 11]

\subsubsection{LCOE and GHG abatement costs}

The resulting LCOE amounts to $0.229 €_{2018} / \mathrm{kWh}$ and the GHG abatement costs calculated were $170 €_{2018} / \mathrm{t} \mathrm{CO}_{2}$ eq.

\subsection{Environmental assessment}

Once the inventories were compiled, the environmental impact assessment of the prototype was carried out. This is the third stage of the LCA or EF methodology, where the environmental results of all the processes and stages are classified according to the selected impact categories from ILCD midpoint+ characterisation method (EC, 2018). In this section the total results are presented according to the different parts of the prototype and the end-of-life:

- The PV panel, which includes the PV module (PV cell), the double laminated, and the manufacturing processes (assembling).

- The electrical installation, which includes the inverters and the cabling.

- The PV junction box.

- The PV mechanical installation, which includes the Sistema Vidrio components.

- The BoS, which includes the panels, the circuit breakers, the surge protective devices, the cabling, the counter and the power supply.

- EoL, where the total BIPV is transported by lorry to a landfill.

Table 12 presents the total results and referred to the functional unit. Subsequently, a figure with the contribution of each part by impact category is presented.

[table 12]

[figure 8]

\subsection{Discussion}


Socioeconomic results show a great stimulation of the economy in terms of goods and services production and added value creation. The obtained multiplier effect of 2.75 expresses that for each monetary unit invested directly in the project, a global economic stimulation of near three times will be created.

The main effects on the production of G\&S an AV creation are produced in the Turkish Electricity, Gas and Water Supply sector followed by the German Electrical and Optical Equipment sector. As for the job creation results, most of them occur in the Electrical and Optical Equipment sector of Taiwan followed by the Spanish Electrical and Optical Equipment sector. Overall, the domestic content of the socioeconomic indicators is around $23 \%$.

The LCOE obtained $\left(0.23 €_{2018} / \mathrm{kWh}\right)$ is in the range of the PV LCOE values published in the literature (IRENA, 2017), but still higher than fossil-based power generation.

In general terms, EF results presented by electrical kWh are good, considering that they cannot be compared with upper-scale facilities. The novel BIPV has the main environmental impact in the manufacturing of the PV modules, and so a change to Best Available Technologies (BATs) in the PV sector would allow obtaining better results for the EF. Nevertheless, in terms of GHG emissions, if the results are compared to the harmonized results from the National Renewable Energy Laboratory (NREL) in the U.S. (NREL, 2018), results are in line with those presented (30-220 $\mathrm{g} \mathrm{CO}_{2} \mathrm{eq} / \mathrm{kWh}$ ) for similar technologies. When compared to other LCA studies, results are also in line with those from Cucchiella et al ((Cucchiella et al., 2015) (71- $\left.92 \mathrm{~g} \mathrm{CO}_{2} \mathrm{eq} / \mathrm{kWh}\right)$ or from Sierra et al, (Sierra et al., 2019) (35 $\mathrm{g} \mathrm{CO}_{2} \mathrm{eq} / \mathrm{kWh}$ ), eventhough these studies considera other boundaries or characterization methods.

Considering the calculated reduction in climate change impact category emissions, the resulting GHG abatement costs $\left(170 €_{2018} / \mathrm{t} \mathrm{CO}_{2}\right.$ eq $)$ are lower than other published 
references that estimate the cost for reducing one ton of $\mathrm{CO}_{2}$ emissions with solar technologies between 500-1000€ (Abrell et al., 2017).

The majority of the calculated indicators present better values than those from fossil fuels. As stated in the introduction section, this research not only helps to identify and assess the opportunities for wide-scale solution-oriented application of photovoltaic power electricity generation in an urban environment, but also could have other practical implications on energy policy regarding the optimal design of BIPV systems, as highlighted in Cucchiella et al. (Cucchiella et al., 2015), Nevertheless, more research and development of this type of infrastructure should be generally implemented in order to decrease the higher value of LCOE, to help to contribute on the PV technologies learning curve.

\section{Conclusions}

The socioeconomic and environmental impacts of an innovative BIPV prototype plant have been analysed to assess the sustainability performance of the system.

The main concluding remarks are the following:

- Overall the socioeconomic effects are relevant in terms of production of G\&S, value added creation and employment generation, although only a $23 \%$ of these effects remain in Turkey. In order to maximize the positive socioeconomic effects in Turkey, the national content of the investments has to be maximized. It should be taken into account that the calculated socioeconomic effects are gross estimations. Net results would be obtained if the economic and employment effects of alternative ways of generating electricity were also analyzed and subtracted. 
- The environmental profile is also good in terms of climate change impacts that show substantial reductions in greenhouse gas emissions compared to fossil fuel alternatives for electricity generation. The highest impacts are produced by the PV manufacturing processes.

- Finally, it should be highlighted that the electricity produced is still more costly than fossil-based technologies and in the highest range of PV technologies, but GHG abatement costs are not so high when compared to other updated references.

\section{Acknowledgements}

The REELCOOP project received funding from the European Union Seventh Framework Programme (FP7/2007-2013), under grant agreement $n^{\circ} 608466$. The authors are grateful to all the partners for their participation in REELCOOP, particularly those involved in the development of the BIPV prototype (http://www.reelcoop.com).

\section{References}

Abrell, J., Kosch, M., Raush, S., 2017. The Economic Cost of Carbon Abatement with Renewable Energy Policies. Zurich. https://doi.org/Abrell, Jan and Kosch, Mirjam and Rausch, Sebastian, The Economic Cost of Carbon Abatement with Renewable Energy Policies (June 15, 2017). CER-ETH - Center of Economic Research at ETH Zurich Working Paper No. 17/273. Available at SSRN:

https://ssrn.com/abstract=2987006 or http://dx.doi.org/10.2139/ssrn.2987006

Agathokleous, R.A., Kalogirou, S.A., Karellas, S., 2018. Exergy analysis of a naturally ventilated Building Integrated Photovoltaic/Thermal (BIPV/T) system. Renew. Energy 128, 541-552. https://doi.org/10.1016/j.renene.2017.06.085

Araz, M., Hepbasli, A., Biyik, E., Shahrestani, M., Yao, R., Essah, E., Shao, L., Oliveira, A.C., Ekren, O., Günerhan, H., 2017. Performance evaluation of a building integrated photovoltaic (BIPV) system combined with a wastewater 
source heat pump (WWSHP) system. Energy Procedia 140, 434-446.

https://doi.org/10.1016/j.egypro.2017.11.155

Baljit, S.S.S., Chan, H.Y., Sopian, K., 2016. Review of building integrated applications of photovoltaic and solar thermal systems. J. Clean. Prod. https://doi.org/10.1016/j.jclepro.2016.07.150

Benini, L., Sala, S., Manfredi, S., Góralczyk, M., 2014. Indicators and targets for the reduction of the environmental impact of EU consumption: Overall environmental impact (resource) indicators - Deliverable 3. European Commision. Ispra, Italy.

Biyik, E., Araz, M., Hepbasli, A., Shahrestani, M., Yao, R., Shao, L., Essah, E., Oliveira, A.C., del Caño, T., Rico, E., Lechón, J.L., Andrade, L., Mendes, A., Atlı, Y.B., 2017. A key review of building integrated photovoltaic (BIPV) systems. Eng. Sci. Technol. an Int. J. 20, 833-858.

https://doi.org/10.1016/J.JESTCH.2017.01.009

Caldés, N., Varela, M., Santamaría, M., Sáez, R., 2009. Economic impact of solar thermal electricity deployment in Spain. Energy Policy 37, 1628-1636. https://doi.org/10.1016/J.ENPOL.2008.12.022

Corona, B., Rúa, C. de la, San Miguel, G., 2016. Socio-economic and environmental effects of concentrated solar power in Spain: A multiregional input output analysis. Sol. Energy Mater. Sol. Cells 156, 112-121. https://doi.org/10.1016/j.solmat.2016.03.014

Costanzo, V., Yao, R., Essah, E., Shao, L., Shahrestani, M., Oliveira, A.C., Araz, M., Hepbasli, A., Biyik, E., 2018. A method of strategic evaluation of energy performance of Building Integrated Photovoltaic in the urban context. J. Clean. Prod. https://doi.org/10.1016/j.jclepro.2018.02.139

Cucchiella, F., D’Adamo, I., Lenny Koh, S.C., 2015. Environmental and economic 
analysis of building integrated photovoltaic systems in Italian regions. J. Clean. Prod. https://doi.org/10.1016/j.jclepro.2013.10.043

Curtius, H.C., 2018. The adoption of building-integrated photovoltaics: barriers and facilitators. Renew. Energy 126, 783-790. https://doi.org/10.1016/J.RENENE.2018.04.001

Debbarma, M., Sudhakar, K., Baredar, P., 2017. Comparison of BIPV and BIPVT: A review. Resour. Technol. 3, 263-271. https://doi.org/10.1016/J.REFFIT.2016.11.013

EC, 2018. ILCD Characterisation factors [WWW Document].

EC, 2013. Commission recommendation of 9 April 2013 on the use of common methods to measure and communicate the life cycle environmental performance of products and organisations. Off. J. Eur. Union L124, 210.

EC, 2010. Directive 2010/31/EU of the European Parliament and of the Council of 19 May 2010 on the energy performance of buildings.

Gholami, H., Røstvik, H.N., Müller-Eie, D., 2019. Holistic economic analysis of building integrated photovoltaics (BIPV) system: Case studies evaluation. Energy Build. https://doi.org/10.1016/j.enbuild.2019.109461

Goe, M., Gaustad, G., 2016. Estimating direct climate impacts of end-of-life solar photovoltaic recovery. Sol. Energy Mater. Sol. Cells 156, 27-36. https://doi.org/10.1016/j.solmat.2016.04.025

Hong, J., Chen, W., Qi, C., Ye, L., Xu, C., 2016. Life cycle assessment of multicrystalline silicon photovoltaic cell production in China. Sol. Energy 133, 283-293. https://doi.org/10.1016/j.solener.2016.04.013

IEA, 2015. Projected costs of generating electricity - 2015 Edition.

IRENA, 2017. Renewable Power Generation Costs in 2017. Abu Dhabi. 
ISO, 2006a. ISO 14044:2006 Environmental management - Life cycle assessment Requirements and guidelines.

ISO, 2006b. ISO 14040:2006 Environmental management - Life cycle assessment Principles and framework.

Jayathissa, P., Jansen, M., Heeren, N., Nagy, Z., Schlueter, A., 2016. Life cycle assessment of dynamic building integrated photovoltaics. Sol. Energy Mater. Sol. Cells 156, 75-82. https://doi.org/10.1016/j.solmat.2016.04.017

Kannan, R., Leong, K.C., Osman, R., Ho, H.K., Tso, C.P., 2006. Life cycle assessment study of solar PV systems: An example of a $2.7 \mathrm{kWp}$ distributed solar PV system in Singapore. Sol. Energy 80, 555-563. https://doi.org/10.1016/j.solener.2005.04.008

Kim, H., Cha, K., Fthenakis, V.M., Sinha, P., Hur, T., 2014. Life cycle assessment of cadmium telluride photovoltaic (CdTe PV) systems. Sol. Energy 103, 78-88. https://doi.org/10.1016/j.solener.2014.02.008

Lamnatou, C., Baig, H., Chemisana, D., Mallick, T.K., 2016. Environmental assessment of a building-integrated linear dielectric-based concentrating photovoltaic according to multiple life-cycle indicators. J. Clean. Prod. https://doi.org/10.1016/j.jclepro.2016.04.094

Latunussa, C.E.L., Ardente, F., Blengini, G.A., Mancini, L., 2016. Life Cycle Assessment of an innovative recycling process for crystalline silicon photovoltaic panels. Sol. Energy Mater. Sol. Cells 156, 101-111. https://doi.org/10.1016/j.solmat.2016.03.020

Leontief, W., 1986. Input-output Economics. Oxford University Press. Ludin, N.A., Mustafa, N.I., Hanafiah, M.M., Ibrahim, M.A., Asri Mat Teridi, M., Sepeai, S., Zaharim, A., Sopian, K., 2018. Prospects of life cycle assessment of 
renewable energy from solar photovoltaic technologies: A review. Renew. Sustain. Energy Rev. 96, 11-28. https://doi.org/10.1016/j.rser.2018.07.048

Manfredi, S., Allacker, K., Chomkhamsri, K., Pelletier, N., Maia de Souza, D., Pant, R., Pennington, D., 2012. Product Environmental Footprint (PEF) Guide. European Commision. Ispra, Italy.

Menoufi, K., Chemisana, D., Rosell, J.I., 2013. Life Cycle Assessment of a Building Integrated Concentrated Photovoltaic scheme. Appl. Energy 111, 505-514. https://doi.org/10.1016/j.apenergy.2013.05.037

Miller, R.E., Blair, P.D., 2009. Input-output analysis : foundations and extensions. Cambridge University Press.

NREL, 2018. Life Cycle Asessment Harmonization [WWW Document].

Sierra, D., Aristizábal, A.J., Hernández, J.A., Ospina, D., 2019. Life cycle analysis of a building integrated photovoltaic system operating in Bogotá, Colombia. Energy Reports 6, 10-19. https://doi.org/10.1016/j.egyr.2019.10.012

Silva, S.M., Mateus, R., Marques, L., Ramos, M., Almeida, M., 2016. Contribution of the solar systems to the nZEB and ZEB design concept in Portugal - Energy, economics and environmental life cycle analysis. Sol. Energy Mater. Sol. Cells 156, 59-74. https://doi.org/10.1016/J.SOLMAT.2016.04.053

ten Raa, T., 2006. The Economics of Input-Output Analysis. Cambridge University Press, Cambridge. https://doi.org/10.1017/CBO9780511610783

Tripathy, M., Yadav, S., Panda, S.K., Sadhu, P.K., 2017. Performance of building integrated photovoltaic thermal systems for the panels installed at optimum tilt angle. Renew. Energy 113, 1056-1069. https://doi.org/10.1016/J.RENENE.2017.06.052

Tsang, M.P., Sonnemann, G.W., Bassani, D.M., 2016. Life-cycle assessment of cradle- 
to-grave opportunities and environmental impacts of organic photovoltaic solar panels compared to conventional technologies. Sol. Energy Mater. Sol. Cells 156, 37-48. https://doi.org/10.1016/j.solmat.2016.04.024

UNSD, 2017. United Nations Statistics Division [WWW Document]. URL https://unstats.un.org

Wiedmann, T., Lenzen, M., Turner, K., Barrett, J., 2007. Examining the global environmental impact of regional consumption activities — Part 2: Review of input-output models for the assessment of environmental impacts embodied in trade. Ecol. Econ. 61, 15-26. https://doi.org/10.1016/J.ECOLECON.2006.12.003 WIOD, 2017a. World Input-Output Database [WWW Document]. URL http://www.wiod.org/home

WIOD, 2017b. WIOD Socio Economic Accounts [WWW Document]. WIOD Socio Econ. Accounts. 


\section{Appendix A. Life Cycle Inventory of the BIPV system}

App.1. PV panel

Solar cells are one of the most important components of the PV panels. Because of the lack of data from the panel PV manufacturer, main data have been extrapolated from the ecoinvent commercial database v3.3. The selected corresponding dataset of the PV cells from ecoinvent has been 'Photovoltaic cell, single Si, at plant'. This dataset considers a surface of one square meter by module.

Technical and experimental data, both provided by ONYX, are presented in tables A.1 and A.2, respectively. More specifically, table A.3 presents the double laminating part which contains the Ethylvinylacetate (EVA) layer.

Table A.1. Technical data of PV panel, modules and cells.

\begin{tabular}{lcc}
\hline Item & Value & Unit \\
\hline PV cells by module & 36 & units \\
\hline PV modules by panel & 48 & units \\
\hline Module surface & 1.2 & $\mathrm{~m}^{2}$ \\
\hline
\end{tabular}

Table A.2. LCI of PV module assembly.

\begin{tabular}{lccc}
\hline Item & Value & Unit \\
\hline INPUTS & & \\
\hline PV cells, 36 cell by module & 1.2 & $\mathrm{~m}^{2}$ \\
\hline Wood crate, packaging & 2.54 & $\mathrm{~kg}$ \\
\hline Wood pallets, packaging & & \\
\hline
\end{tabular}




\begin{tabular}{|c|c|c|}
\hline Plastic film, packaging & 30 & $\mathrm{~g}$ \\
\hline Transport, plane, from producers to ONYX: $10496 \mathrm{~km}$ & 5.64 & tkm \\
\hline Electricity & 0.83 & $\mathrm{kWh}$ \\
\hline Natural gas & 2.23 & MJ \\
\hline \multicolumn{3}{|l|}{ OUTPUTS } \\
\hline Carbon dioxide & 1.27 & $\mathrm{Kg}$ \\
\hline Hydraulic and lubricating oil & 0.000216 & $\mathrm{~kg}$ \\
\hline Plastic & 0.02118 & $\mathrm{~kg}$ \\
\hline Paper and cardboard & 0.02824 & $\mathrm{~kg}$ \\
\hline Glass & 0.04235 & $\mathrm{~kg}$ \\
\hline Wood & 0.05647 & $\mathrm{~kg}$ \\
\hline Iron and steel & 0.00424 & $\mathrm{~kg}$ \\
\hline Metals & 0.21176 & $\mathrm{~kg}$ \\
\hline $\begin{array}{l}\text { Waste: Absorbents, filter materials (including oil filters not } \\
\text { otherwise specified), wiping cloths, protective clothing }\end{array}$ & 0.00706 & $\mathrm{~kg}$ \\
\hline contaminated by dangerous substances & & \\
\hline
\end{tabular}

Table A.3. LCI of materials and processes to manufacture the double laminating part.

\begin{tabular}{lll}
\hline Item & Value & Unit \\
\hline EVA layer & 3.34 & $\mathrm{~kg}$ \\
\cline { 2 - 3 } & & \\
\cline { 2 - 3 } & 86.47 & tkm
\end{tabular}




\begin{tabular}{|c|c|c|}
\hline \multirow[t]{3}{*}{ Flux part } & 27.46 & $\mathrm{~g}$ \\
\hline & 0.35 & $\mathrm{~g}$ \\
\hline & 0.03 & $\mathrm{tkm}$ \\
\hline \multirow[t]{2}{*}{ Silicone } & 0.03 & $\mathrm{~kg}$ \\
\hline & 0.29 & $\mathrm{tkm}$ \\
\hline \multirow[t]{5}{*}{ Ribbon } & 27.27 & $\mathrm{~g}$ \\
\hline & 0.84 & g \\
\hline & 0.14 & $\mathrm{~g}$ \\
\hline & 0.02 & $\mathrm{~kg}$ \\
\hline & 0.11 & tkm \\
\hline \multirow[t]{5}{*}{ Ribbon L } & 1.02 & $\mathrm{~g}$ \\
\hline & 0.005 & $\mathrm{~g}$ \\
\hline & 0.03 & $\mathrm{~g}$ \\
\hline & 0.0011 & $\mathrm{~kg}$ \\
\hline & 0.004 & $\mathrm{tkm}$ \\
\hline \multirow[t]{3}{*}{ Tempered glass } & 24 & $\mathrm{~kg}$ \\
\hline & 24 & $\mathrm{~kg}$ \\
\hline & 3.6 & $\mathrm{tkm}$ \\
\hline \multirow[t]{2}{*}{ Lateral tape } & 0.001 & $\mathrm{~g}$ \\
\hline & 0.006 & $\mathrm{tkm}$ \\
\hline
\end{tabular}




\begin{tabular}{lll}
\hline Internal tape & $3.46 \mathrm{E}-07$ & $\mathrm{~g}$ \\
\cline { 2 - 3 } & & \\
& & \\
& & $\mathrm{tkm}$ \\
\cline { 2 - 3 } Transparent TEDLAR & 0.79 & $\mathrm{~kg}$ \\
& & $\mathrm{tkm}$ \\
\hline Isopropyl & 33.08 & $\mathrm{~g}$ \\
\cline { 2 - 3 } & 0.006 & $\mathrm{tkm}$ \\
\hline Labels & & $\mathrm{g}$ \\
\hline
\end{tabular}

App.2. Mechanical installation (Sistema Vidrio)

Table A.4 presents the LCI of the manufacturing of the mechanical installation.

Table A.4. LCI of mechanical installation.

\begin{tabular}{llll}
\hline Item & Value & Unit \\
& & \\
\hline Aluminium Support (53 units) and Hold brackets (105 units) & 31.6 & $\mathrm{~kg}$ \\
\hline Aluminium anodized staples (197 units) & 9.85 & $\mathrm{~kg}$ \\
\hline Screw (Stainless Steel, 593 units) & 3.75 & $\mathrm{~kg}$ \\
\hline Concrete anchor (Stainless Steel, 106 units) & 6.05 & $\mathrm{~kg}$ \\
\hline Nylon anchor (Stainless Steel, 55 units) & 3.14 & $\mathrm{~kg}$ \\
\hline Bimetal anchor (Stainless Steel, 55 units) & 0.61 & $\mathrm{~kg}$ \\
\hline Fastening (screw and anchors) & 13.55 & $\mathrm{~kg}$ \\
\hline Vertical shapes (aluminium) & 117 & $\mathrm{~kg}$ \\
\hline Glass adhesive & 3.6 & $\mathrm{~g}$ \\
\hline
\end{tabular}


App.3. Electrical installation

Table A.5 shows the LCI of the manufacturing of the inverter and cables.

Table A.5. LCI of electrical installation.

\begin{tabular}{lcl}
\hline Item & Value & Unit \\
\hline Inverter, 2500W & 3 & units \\
\hline Cabling & 2 & $\mathrm{~m}$ \\
\hline
\end{tabular}

App.4. Straddle edge PV Glass: Junction box

The LCI of the junction box and their corresponding devices are shown in table A.6.

Table A.6. LCI of the junction box device.

\begin{tabular}{|c|c|c|c|}
\hline Item & Components & Value & Unit \\
\hline Junction & Copper & 85 & $\mathrm{~g}$ \\
\hline \multirow[t]{2}{*}{ box } & Polyphenylene sulfide & 119 & $\mathrm{~g}$ \\
\hline & Wire drawing process & 204 & $\mathrm{~g}$ \\
\hline \multirow[t]{3}{*}{ Cabling } & Copper & 68.06 & $\mathrm{~g}$ \\
\hline & Polyols & 2.05 & $\mathrm{~g}$ \\
\hline & Wire drawing process & 70.11 & $\mathrm{~g}$ \\
\hline \multirow[t]{6}{*}{ Diode } & Nickel & 0.00007 & g \\
\hline & Gold & 0.0008 & $\mathrm{~g}$ \\
\hline & Synthetic rubber & 0.001 & $\mathrm{~g}$ \\
\hline & Silicone & 0.005 & g \\
\hline & Silver & 0.00006 & $\mathrm{~g}$ \\
\hline & Tin & $2.11 \mathrm{E}-05$ & $\mathrm{~g}$ \\
\hline
\end{tabular}




\begin{tabular}{|c|c|c|c|}
\hline & Lead & 0.003 & $\mathrm{~g}$ \\
\hline & Carbon black & 0.002 & g \\
\hline & Antimony & 0.007 & g \\
\hline & Chemicals organic & 0.008 & $\mathrm{~g}$ \\
\hline & Epoxy resin & 0.24 & g \\
\hline & Sand & 0.63 & g \\
\hline & Tin & 0.04 & $\mathrm{~g}$ \\
\hline & Copper & 1.04 & $\mathrm{~g}$ \\
\hline & Wire drawing process & 1.99 & $\mathrm{~g}$ \\
\hline Connector & Copper & 15.75 & g \\
\hline & Polyamide 6.6 & 5.25 & $\mathrm{~g}$ \\
\hline & Wire drawing process & 21 & g \\
\hline & Transport, lorry & 0.009 & tkm \\
\hline Silicone & Silicone & 41.1 & $\mathrm{~g}$ \\
\hline
\end{tabular}

App.5. Components of the Balance of the System (BoS)

Tables A.7 to A.13 show the LCI of the different devices that are part of the BoS.

Table A.7. LCI of the surge protective device.

\begin{tabular}{lll}
\hline Item & Value & Unit \\
\hline Metal, steel & 17.76 & $\mathrm{~g}$ \\
\hline Glass fiber & 7.29 & $\mathrm{~g}$ \\
\hline Copper & 25.56 & $\mathrm{~g}$ \\
\hline Polycarbonate & & \\
\hline
\end{tabular}




\begin{tabular}{lcl}
\hline Cardboard & 20.51 & $\mathrm{~g}$ \\
\hline Glass moulding, injection & 42.7 & $\mathrm{~g}$ \\
\hline Metal, steel, hot rolling & 43.32 & $\mathrm{~g}$ \\
& & \\
\hline
\end{tabular}

Table A.8. LCI of the mini circuit breaker.

\begin{tabular}{lrl}
\hline Item & Value & Unit \\
\hline Steel & $50 \mathrm{~g}$ \\
\hline Non-iron alloy components, aluminium. & $1.25 \mathrm{~g}$ \\
\hline Copper and copper alloys & $12.37 \mathrm{~g}$ \\
\hline Silver & $0.12 \mathrm{~g}$ \\
\hline Zinc & $2.5 \mathrm{~g}$ \\
\hline Aluminum & $3.75 \mathrm{~g}$ \\
\hline Aluminum oxide & $2.5 \mathrm{~g}$ \\
\hline Silicon dioxide/glass & $8.75 \mathrm{~g}$ \\
\hline Plastic of housing, polycarbonate & $40.62 \mathrm{~g}$ \\
\hline other plastic material, glass fibre reinfirced & 3.12 & $\mathrm{~g}$ \\
\hline Injection moulding & 43.75 & $\mathrm{~g}$ \\
\hline Hot Rolling, steel & 81.25 & $\mathrm{~g}$ \\
\hline
\end{tabular}

Table A.9. LCI of the termomagnetic circuit breaker.

\begin{tabular}{lcc}
\hline Item & Value & Unit \\
\hline RESOURCES & & \\
& & $\mathrm{g}$ \\
\hline Water & 197 & \\
\hline
\end{tabular}




\begin{tabular}{lcc}
\hline Wood & 0.03 & $\mathrm{~g}$ \\
\hline Baryte & 0.003 & $\mathrm{~g}$ \\
\hline copper & 0.14 & $\mathrm{~g}$ \\
\hline Iron & 0.31 & $\mathrm{~g}$ \\
\hline Sand & 0.15 & $\mathrm{~g}$ \\
\hline Silver & 0.003 & $\mathrm{~g}$ \\
\hline Coal & 0.78 & $\mathrm{~g}$ \\
\hline Lignite & 0.09 & $\mathrm{~g}$ \\
\hline Natural gas & 0.61 & $\mathrm{~g}$ \\
\hline Crude oil & 1.12 & $\mathrm{~g}$ \\
\hline Uranium & 0.00002 & $\mathrm{~g}$ \\
\hline INPUTS & & $\mathrm{g}$ \\
\hline Nard coal & & $\mathrm{g}$ \\
\hline Acrylonitrile-butadiene-styrene (ABS) & & $\mathrm{g}$ \\
\hline copper & & $\mathrm{g}$ \\
\hline Polyester (20\% glass fibre) & & $\mathrm{g}$ \\
\hline Polyester (25\% glass fibre) & & $\mathrm{g}$ \\
\hline Polyamide (25\% glass fibre) & & $\mathrm{g}$ \\
\hline Polyamide (30\% glass fibre) & & $\mathrm{g}$ \\
\hline Polyamide, Nylon 6 & & $\mathrm{g}$ \\
\hline Polycarbonate (30\% glass fibre) & & $\mathrm{g}$ \\
\hline
\end{tabular}




\begin{tabular}{llll}
\hline & Lignite & 0.98 & MJ \\
\cline { 2 - 4 } & Heavy fuel oil & 50.7 & MJ \\
\cline { 2 - 4 } & Nuclear & 11.1 & MJ \\
\cline { 2 - 4 } & Hydropower & 5.21 & MJ \\
\cline { 2 - 4 } & Peat & 0.77 & MJ \\
\cline { 2 - 4 } & Mix & 34.83 & MJ \\
\hline OUTPUTS & & & \\
\hline Waste hazardous & & 0.012 & $\mathrm{Kg}$ \\
\hline Waste non-hazardous & & 0.978 & $\mathrm{Kg}$ \\
\hline
\end{tabular}

Table A.10. LCI of the counter.

\begin{tabular}{lcl}
\hline Item & Value & Unit \\
& & \\
\hline Polycarbonate & 173 & $\mathrm{~g}$ \\
& & \\
\hline Polyamide 6.6 & 203.64 & $\mathrm{~g}$ \\
\hline Steel & 205.38 & $\mathrm{~g}$ \\
\hline Copper & 205.38 & $\mathrm{~g}$ \\
\hline Injection moulding process & 376.64 & $\mathrm{~g}$ \\
& & \\
\hline Hot rolling process & 410.76 & $\mathrm{~g}$ \\
\hline
\end{tabular}

Table A.11. LCI of the Panel control and Panel AC.

\begin{tabular}{lll}
\hline Item & Value & Unit \\
& & \\
\hline Polyester resin & 2.98 & $\mathrm{~kg}$ \\
\hline Injection moulding process & 2.98 & $\mathrm{~kg}$ \\
\hline
\end{tabular}




\begin{tabular}{lcc}
\hline Steel & 0.34 & $\mathrm{~kg}$ \\
\hline Hot rolling process & 0.34 & $\mathrm{~kg}$ \\
\hline Transport, lorry & 1.68 & $\mathrm{tkm}$ \\
\hline
\end{tabular}

Table A.12. LCI of the Panel DC.

\begin{tabular}{lcc}
\hline Item & Value & Unit \\
\hline Polyester resin & 2.1 & $\mathrm{~kg}$ \\
\hline Injection moulding process & 2.1 & $\mathrm{~kg}$ \\
\hline Steel & 0.28 & $\mathrm{~kg}$ \\
\hline Hot rolling process & 0.28 & $\mathrm{~kg}$ \\
\hline Transport, lorry & 1.20 & $\mathrm{tkm}$ \\
\hline
\end{tabular}

Table A.13. LCI of the power supply.

\begin{tabular}{lcc}
\hline Item & Value & Unit \\
\hline Polycarbonate & 340 & $\mathrm{~g}$ \\
\hline Injection moulding process & 340 & $\mathrm{~g}$ \\
\hline
\end{tabular}

App.6. End of Life

Finally, the whole components of the BIPV are considered to go to a landfill in the same province in Turkey to an average distance of $70 \mathrm{~km}$. Only transportation by truck is considered. The assumed amount of waste is $1670 \mathrm{~kg}$, and then a total of $116.9 \mathrm{tkm}$ were considered. 
Table 1. Technical specifications of the BIPV modules.

\begin{tabular}{ll}
\hline & Electrical data test conditions \\
\hline Nominal peak power $\left(\mathrm{W}_{\mathrm{p}}\right)$ & 155 \\
\hline Open circuit voltaje $(\mathrm{V})$ & 23 \\
\hline Short-circuit current $(\mathrm{A})$ & 8.62 \\
\hline Voltage at nominal power $(\mathrm{V})$ & 18 \\
\hline Current at nominal power $(\mathrm{A})$ & 8.40 \\
\hline Power tolerance not to exceed $(\%)$ & \pm 10 \\
\hline \multicolumn{2}{c}{ Mechanical description } \\
\hline Length $(\mathrm{mm})$ & 1600 \\
\hline Width $(\mathrm{mm})$ & 750 \\
\hline Thickness $(\mathrm{mm})$ & 8.5 \\
\hline Surface area $\left(\mathrm{m}^{2}\right)$ & 1.2 \\
\hline Weight density $\left(\mathrm{kg} / \mathrm{m}^{2}\right)$ & 20 \\
\hline Cell type & 6 " mono-crystalline solar cells \\
\hline Transparency degree $(\%)$ & 30 \\
\hline Layer type & 4 mm tempered glass \\
\hline & Limits \\
\hline Maximum system voltage $(\mathrm{V})$ & 1000 \\
\hline Operating module temperature $\left({ }^{\circ} \mathrm{C}\right)$ & -40 to +85 \\
\hline
\end{tabular}


Table 2. PV investment cost disaggregation and manufacturing country.

\begin{tabular}{|c|c|c|}
\hline & $€_{2018}$ (Total) & Country \\
\hline \multicolumn{3}{|l|}{ PV module costs } \\
\hline Cells & 3106.37 & Taiwan \\
\hline Glass (front) & 1341.10 & Spain \\
\hline Glass (back) & 923.87 & Spain \\
\hline Perimeter tape & 40.15 & Spain \\
\hline Mylar & 1.35 & Spain \\
\hline Box & 298.02 & Czech Republic \\
\hline Wires & 49.67 & Czech Republic \\
\hline Silicone & 15.73 & Belgium \\
\hline EVA (Ethylene Vinyl Acetate) & 330.41 & Spain \\
\hline Copper connections & 29.80 & Finland \\
\hline Connections with "L" form & 111.76 & Finland \\
\hline Tedlar (transparent) & 124.18 & Italia \\
\hline Flux & 37.15 & Spain \\
\hline Alcohol & 3.93 & Spain \\
\hline Total PV module parts & 6413.48 & \\
\hline Personnel cost & 2434.78 & $\begin{array}{l}\text { Assigned } 48 \% \text { to Taiwan, the rest to } \\
\text { Spain }\end{array}$ \\
\hline Inverter + cluster controller & 3523.49 & Germany \\
\hline Metallic Structure (Aluminium) & 1549.72 & Spain \\
\hline Electricity needed & 581.14 & Assigned $48 \%$ to Taiwan, rest to Spain \\
\hline Packaging & 282.50 & Spain \\
\hline Total PV module manufacturing & 14785.22 & \\
\hline \multicolumn{3}{|l|}{ Equipment costs } \\
\hline AC electrical panel & 20.70 & Turkey (Istanbul) \\
\hline Controller & 20.70 & Turkey (Istanbul) \\
\hline DC electrical panel & 7.45 & Turkey (Istanbul) \\
\hline Circuit breaker (type 1) & 2.07 & Germany \\
\hline Surge protective device (type 1 ) & 156.05 & France \\
\hline Surge protective device (type 2) & 125.42 & France \\
\hline Circuit breaker (type 2) & 2.38 & Germany \\
\hline Counter & 22.25 & Turkey (Istanbul) \\
\hline Residual Current Relay & 23.59 & Italy \\
\hline Surge Protective Device (type 3) & 253.11 & France \\
\hline Surge Protective Device (type 4) & 66.85 & Bulgaria \\
\hline Thermomagnetic Circuit Breaker & 63.02 & Italy \\
\hline Cable Conduit & 202.82 & Turkey (Istanbul) \\
\hline AC cable & 371.91 & Turkey (Kayseri) \\
\hline DC cables $(\mathrm{x} 4)$ & 248.35 & Germany \\
\hline Ground cable (copper) & 77.51 & Turkey (Kayseri) \\
\hline Cable strap & 107.00 & Turkey (Izmir) \\
\hline Power supply & 114.66 & Poland \\
\hline $\begin{array}{l}\text { Total equipment costs } \\
\text { TOTAL INVESTMENT COSTS }\end{array}$ & $\begin{array}{r}1885.82 \\
16671.04\end{array}$ & \\
\hline
\end{tabular}


Table 3. Operation and maintenance costs assumptions.

\begin{tabular}{lc}
\hline O\&M annual cost $\left(€_{2018} / \mathrm{kW}\right)$ & 41.39 \\
\hline Plant life expectancy (years) & 30 \\
\hline Modules degradation (yearly) & $0.6 \%$ \\
\hline Discount rate & $4 \%$ \\
\hline
\end{tabular}


Table 4. Demand vector.

\begin{tabular}{|c|c|c|c|c|}
\hline Country & $\begin{array}{l}\text { WIOD Economic } \\
\text { sector }\end{array}$ & $\begin{array}{l}\text { Investment } \\
\text { costs }\end{array}$ & $\begin{array}{l}\text { O\&M } \\
\text { costs }\end{array}$ & $\begin{array}{l}\text { Total costs (US\$ } \\
2011)\end{array}$ \\
\hline BEL & $\begin{array}{l}\text { Chemicals and } \\
\text { Chemical Products }\end{array}$ & 16.1 & - & 16.1 \\
\hline $\mathrm{CZE}$ & $\begin{array}{l}\text { Chemicals and } \\
\text { Chemical Products }\end{array}$ & 356.3 & - & 356.3 \\
\hline DEU & $\begin{array}{l}\text { Electrical and } \\
\text { Optical Equipment }\end{array}$ & 3869.9 & - & 3869.9 \\
\hline ESP & $\begin{array}{l}\text { Wood and Products } \\
\text { of Wood and Cork }\end{array}$ & 289.5 & - & 289.5 \\
\hline ESP & $\begin{array}{l}\text { Chemicals and } \\
\text { Chemical Products }\end{array}$ & 380.8 & - & 380.8 \\
\hline ESP & Rubber and Plastics & 42.5 & - & 42.5 \\
\hline ESP & $\begin{array}{l}\text { Other Non-Metallic } \\
\text { Mineral }\end{array}$ & 2321.1 & - & 2321.1 \\
\hline ESP & $\begin{array}{l}\text { Basic Metals and } \\
\text { Fabricated Metal }\end{array}$ & 1588.1 & - & 1588.1 \\
\hline ESP & $\begin{array}{l}\text { Electricity, Gas and } \\
\text { Water Supply }\end{array}$ & 307.1 & - & 307.1 \\
\hline FIN & $\begin{array}{l}\text { Electrical and } \\
\text { Optical Equipment }\end{array}$ & 145.1 & - & 145.1 \\
\hline FR & $\begin{array}{l}\text { Electrical and } \\
\text { Optical Equipment }\end{array}$ & 547.8 & - & 547.8 \\
\hline IT & $\begin{array}{l}\text { Chemicals and } \\
\text { Chemical Products }\end{array}$ & 127.3 & - & 127.3 \\
\hline IT & $\begin{array}{l}\text { Electrical and } \\
\text { Optical Equipment }\end{array}$ & 88.8 & - & 88.8 \\
\hline POL & $\begin{array}{l}\text { Electrical and } \\
\text { Optical Equipment }\end{array}$ & 117.5 & - & 117.5 \\
\hline TUR & $\begin{array}{l}\text { Electrical and } \\
\text { Optical Equipment }\end{array}$ & 850.8 & - & 850.8 \\
\hline TUR & $\begin{array}{l}\text { Electricity, Gas and } \\
\text { Water Supply }\end{array}$ & 0.0 & 5457.1 & 5457.1 \\
\hline TWN & $\begin{array}{l}\text { Electrical and } \\
\text { Optical Equipment }\end{array}$ & 3183.3 & - & 3183.3 \\
\hline TWN & $\begin{array}{l}\text { Electricity, Gas and } \\
\text { Water Supply }\end{array}$ & 288.4 & - & 288.4 \\
\hline ROW & $\begin{array}{l}\text { Electrical and } \\
\text { Optical Equipment }\end{array}$ & 68.5 & - & 68.5 \\
\hline \multicolumn{2}{|c|}{ Total costs (US\$2011) } & 14588.7 & 5457.1 & 20045.8 \\
\hline
\end{tabular}


Table 5. Disaggregated final demand of G\&S.

\begin{tabular}{ll}
\hline & Final demand of G\&S $\left(\boldsymbol{\epsilon}_{\mathbf{2 0 1 5}}\right)$ \\
\hline Investment & 14236.16 \\
\hline O\&M & 5325.18 \\
\hline Induced demand & 1948.94 \\
\hline Total demand & 21453.89 \\
\hline
\end{tabular}

Table 6. Specific technical and operational data of the BIPV.

\begin{tabular}{lcc}
\hline Item & Value & Units \\
\hline PV cells life expectancy & $\mathbf{3 0}$ & Years \\
\hline Cabling life expectancy & $\mathbf{2 5}$ & Years \\
\hline Plant life expectancy & $\mathbf{2 5}$ & Years \\
\hline Annual modules degradation & $\mathbf{0 . 6}$ & \% \\
\hline Nominal Power & $\mathbf{7 . 4 4}$ & $\mathbf{k W h}$ electrical \\
\hline Estimated operation in hours by year & $\mathbf{1 5 0 0}$ & Hours/yr \\
\hline
\end{tabular}


Table 7. List of components in BIPV.

\begin{tabular}{|c|c|c|c|c|}
\hline Component & Units & Brand & Model & Data supplier \\
\hline PV modules & 48 & ONYX & - & ONYX, Spain \\
\hline Inverter & 1 & SMA & $7000 \mathrm{TL}$ & ONYX, Spain \\
\hline Junction box & 1 & ONYX & - & ONYX, Spain \\
\hline $\begin{array}{l}\text { Mounting } \\
\text { Mechanism }\end{array}$ & 1 & ONYX & Sistema Vidrio & ONYX, Spain \\
\hline AC Panel & 1 & $\begin{array}{l}\text { Çetinkaya } \\
\text { Pano }\end{array}$ & ÇP 505 & YU, Turkey \\
\hline Control Panel & 1 & $\begin{array}{l}\text { Çetinkaya } \\
\text { Pano }\end{array}$ & ÇP 505 & YU, Turkey \\
\hline DC Panel & 1 & $\begin{array}{l}\text { Çetinkaya } \\
\text { Pano }\end{array}$ & ÇP 501 & YU, Turkey \\
\hline Circuit Breaker & 2 & $\mathrm{ABB}$ & S 201M C 10 & YU, Turkey \\
\hline $\begin{array}{l}\text { Surge Protective } \\
\text { Device }\end{array}$ & 2 & $\mathrm{ABB}$ & $\begin{array}{l}\text { OVR T2 40-275- } \\
\text { C }\end{array}$ & YU, Turkey \\
\hline $\begin{array}{l}\text { Surge Protective } \\
\text { Device }\end{array}$ & 2 & $\mathrm{ABB}$ & OVR T2 $70 \mathrm{~N} \mathrm{C}$ & YU, Turkey \\
\hline Circuit Breaker & 1 & Siemens & 5SQ21 C6 & YU, Turkey \\
\hline Counter & 1 & Köhler & AEL.TF.16-2 & YU, Turkey \\
\hline $\begin{array}{l}\text { Residual Current } \\
\text { Relay }\end{array}$ & 1 & $\mathrm{ABB}$ & FH204 AC 25A & YU, Turkey \\
\hline $\begin{array}{l}\text { Surge Protective } \\
\text { Device }\end{array}$ & 3 & $\mathrm{ABB}$ & $\begin{array}{l}\text { OVR L 40-275 } \\
\text { C }\end{array}$ & YU, Turkey \\
\hline $\begin{array}{l}\text { Surge Protective } \\
\text { Device }\end{array}$ & 1 & $\mathrm{ABB}$ & $\begin{array}{l}\text { OVR N 80-275 } \\
\text { C }\end{array}$ & YU, Turkey \\
\hline $\begin{array}{l}\text { Thermomagnetic } \\
\text { Circuit Breaker }\end{array}$ & 1 & $\mathrm{ABB}$ & XT1N 160 & YU, Turkey \\
\hline Cable Conduit & $50 \mathrm{~m}$ & $\begin{array}{l}\text { Emit } \\
\text { Metal }\end{array}$ & EMT-10.10 & YU, Turkey \\
\hline DC Cable & $160 \mathrm{~m}$ & $\begin{array}{l}\text { Multi } \\
\text { Contact }\end{array}$ & $1 * 6 \mathrm{~mm}^{2}$ & YU, Turkey \\
\hline AC Cable & $9 \mathrm{~m}$ & HES & $4 * 10 \mathrm{~mm}^{2}$ & YU, Turkey \\
\hline $\begin{array}{l}\text { Ground Cable } \\
\text { (Copper) }\end{array}$ & $90 \mathrm{~m}$ & HES & $1 * 10 \mathrm{~mm}^{2}$ & YU, Turkey \\
\hline $\begin{array}{l}\text { Cable Strap (for } \\
\text { ground cable) }\end{array}$ & 48 & EMİ & - & YU, Turkey \\
\hline
\end{tabular}




\begin{tabular}{llll}
\hline \multirow{2}{*}{$\begin{array}{l}\text { Power Supply } \\
\end{array}$} & Phoenix & $\begin{array}{l}\text { UNO- } \\
\text { PS/1AC/24DC/1 } \\
\text { 00W }\end{array}$ & YU, Turkey \\
& & \\
\hline
\end{tabular}

Table 8. Production of G\&S and AV creation.

\begin{tabular}{lllll}
\hline Socioeconomic effects & Total & $\begin{array}{l}\text { Investment } \\
\text { phase }\end{array}$ & $\begin{array}{l}\text { O\&M } \\
\text { phase }\end{array}$ & $\begin{array}{l}\text { Induced } \\
\text { effects }\end{array}$ \\
\hline Production of G\&S $\left(\boldsymbol{\epsilon}_{\mathbf{2 0 1 8}}\right)$ & 58921.72 & 36748.44 & 12339.58 & 9833.81 \\
\hline AVcreation $\left(\boldsymbol{\epsilon}_{\mathbf{2 0 1 8}}\right)$ & 21547.74 & 12234.13 & 4825.38 & 4488.24 \\
\hline
\end{tabular}

Table 9. Assumptions considered for the estimation of direct FTE for Spain and

Taiwan.

\begin{tabular}{|c|c|}
\hline Total personnel cost $\left(\epsilon_{2018}\right)$ : & 2434.78 \\
\hline Total manufacturing days: & 6 days \\
\hline 4 manufacturing days & $\begin{array}{l}2 \text { days Taiwan, } 2 \text { days } \\
\text { Spain }\end{array}$ \\
\hline 1 preparation day & Spain \\
\hline 1 packacking day & Spain \\
\hline Daily cost $\left(€_{2018}\right)$ & 405.75 \\
\hline Average Wage Spain (daily) $\left(\boldsymbol{\epsilon}_{2018}\right)[32]$ & 75.44 \\
\hline Spanish employees paid daily $\left(\boldsymbol{(}_{\mathbf{2 0 1 8}}\right)(392 / 73)$ & 5.59 \\
\hline Spanish employees paid in 4 days $\left(\boldsymbol{(}_{\mathbf{2 0 1 8}}\right)$ & 22.35 \\
\hline Equivalent 1 year FTE Spanish employees & 0.059 \\
\hline Average Wage Taiwan (daily) [33] & 47.60 \\
\hline Taiwanese employees paid daily $\left(\boldsymbol{(}_{\mathbf{2 0 1 8}}\right)(392 / 46)$ & 8.80 \\
\hline Taiwanese employees paid in 2 days $\left(\boldsymbol{\epsilon}_{\mathbf{2 0 1 8}}\right)$ & 17.59 \\
\hline Equivalent 1 year FTE Taiwanese employees & 0.047 \\
\hline Total FTE Spanish + Taiwanese employees & 0.11 \\
\hline
\end{tabular}


Table 10. Direct and indirect FTE effects in the investment and O\&M phases.

\begin{tabular}{lcc}
\hline & Investment & O\&M \\
\hline Direct effects & 0.34 & 0.07 \\
\hline Indirect effects & 0.45 & 0.13 \\
\hline Total & 0.79 & 0.20 \\
\hline
\end{tabular}

Table 11. Main economic sectors responsible for the largest shares socioeconomic effects (CHN: China; DEU: Germany; ESP: Spain; TUR: Turkey; TWN: Taiwan; RoW Rest of the world).

\begin{tabular}{|c|c|c|c|}
\hline & $\operatorname{G\& S}\left(\epsilon_{2018}\right)$ & $\operatorname{AV}\left(€_{2018}\right)$ & Jobs (FTE) \\
\hline CHN Electrical and Optical Equipment & 873.60 & 0.00 & 0.05 \\
\hline DEU Electrical and Optical Equipment & 3925.33 & 1502.78 & 0.04 \\
\hline DEU Real Estate Activities & 0.00 & 402.25 & 0.00 \\
\hline $\begin{array}{l}\text { DEU Renting of M\&Eq and Other Business } \\
\text { Activities }\end{array}$ & 0.00 & 381.92 & 0.00 \\
\hline ESP Other Non-Metallic Mineral & 2392.50 & 728.24 & 0.02 \\
\hline ESP Basic Metals and Fabricated Metal & 2061.39 & 575.06 & 0.02 \\
\hline ESP Electrical and Optical Equipment & 0.00 & 0.00 & 0.05 \\
\hline ESP Electricity, Gas and Water Supply & 917.69 & 0.00 & 0.00 \\
\hline ESP Hotels and Restaurants & 653.23 & 377.23 & 0.00 \\
\hline ESP Real Estate Activities & 0.00 & 434.74 & 0.00 \\
\hline TUR Electrical and Optical Equipment & 1003.40 & 0.00 & 0.03 \\
\hline TUR Electricity, Gas and Water Supply & 8777.97 & 3216.76 & 0.11 \\
\hline TUR Construction & 31.48 & 13.56 & 0.00 \\
\hline $\begin{array}{l}\text { TWN Electrical and Optical Equipment } \\
\text { TWN Wholesale Trade and Commission }\end{array}$ & 3080.45 & 665.40 & 0.14 \\
\hline Trade & 0.00 & 356.40 & 0.00 \\
\hline RoW Mining and Quarrying & 781.33 & 0.00 & 0.00 \\
\hline National content $(\%)$ & $23 \%$ & $24 \%$ & $23 \%$ \\
\hline
\end{tabular}


Table 12. Global results of the novel BIPV by impact category.

\begin{tabular}{llcc}
\hline Impact category & Unit & Total & Total per kWh \\
\hline Climate change & $\mathrm{kg} \mathrm{CO}_{2}$ eq & $1.66 \mathrm{E}+04$ & $9.78 \mathrm{E}-02$ \\
\hline Ozone depletion & $\mathrm{kg} \mathrm{CFC}-11 \mathrm{eq}$ & $3.39 \mathrm{E}-03$ & $2.00 \mathrm{E}-08$ \\
\hline Human toxicity, non-cancer effects & $\mathrm{CTUh}$ & $1.27 \mathrm{E}-02$ & $7.46 \mathrm{E}-08$ \\
\hline Human toxicity, cancer effects & $\mathrm{CTUh}$ & $1.91 \mathrm{E}-03$ & $1.12 \mathrm{E}-08$ \\
\hline Particulate matter & $\mathrm{kg} \mathrm{PM} 2.5 \mathrm{eq}$ & $8.06 \mathrm{E}+00$ & $4.74 \mathrm{E}-05$ \\
\hline Ionizing radiation $\mathrm{HH}$ & $\mathrm{kBq} \mathrm{U} 235 \mathrm{eq}$ & $5.54 \mathrm{E}+03$ & $3.26 \mathrm{E}-02$ \\
\hline Ionizing radiation E (interim) & $\mathrm{CTUe}$ & $1,68 \mathrm{E}-02$ & $9.89 \mathrm{E}-08$ \\
\hline Photochemical ozone formation & $\mathrm{kg} \mathrm{NMVOC}$ & & \\
\hline Acidification & $\mathrm{eq}$ & $6.96 \mathrm{E}+01$ & $4.10 \mathrm{E}-04$ \\
\hline Terrestrial eutrophication & $\mathrm{molc} \mathrm{H}+\mathrm{eq}$ & $1.02 \mathrm{E}+02$ & $6.01 \mathrm{E}-04$ \\
\hline Freshwater eutrophication & $\mathrm{molc} \mathrm{N}$ eq & $2.05 \mathrm{E}+02$ & $1.20 \mathrm{E}-03$ \\
\hline Marine eutrophication & $\mathrm{kg} \mathrm{P} \mathrm{eq}$ & $1.16 \mathrm{E}+01$ & $6.82 \mathrm{E}-05$ \\
\hline Freshwater ecotoxicity & $\mathrm{kg} \mathrm{N}$ eq & $2.25 \mathrm{E}+01$ & $1.32 \mathrm{E}-04$ \\
\hline Land use & $\mathrm{CTUe}$ & $2.64 \mathrm{E}+05$ & $1.55 \mathrm{E}+00$ \\
\hline Water resource depletion & $\mathrm{kg} \mathrm{C} \mathrm{deficit}$ & $2.19 \mathrm{E}+04$ & $1.29 \mathrm{E}-01$ \\
\hline Mineral, fossil \& ren resour depletion & $\mathrm{mg}$ water eq & $2.36 \mathrm{E}+02$ & $1.39 \mathrm{E}-03$ \\
\hline & & $5.91 \mathrm{E}+00$ & $3.48 \mathrm{E}-05$ \\
\hline
\end{tabular}




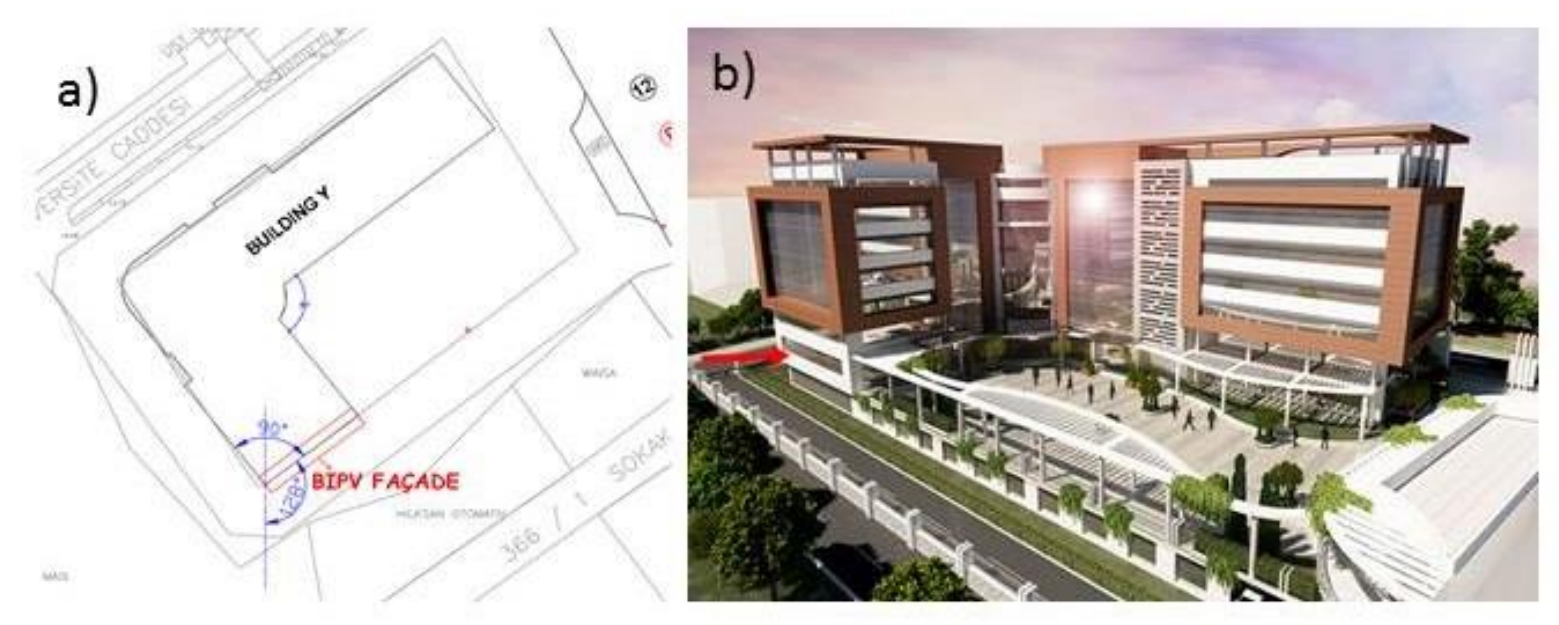

Figure 1. a) The layout of the installation building, b) 3D-model of the building.

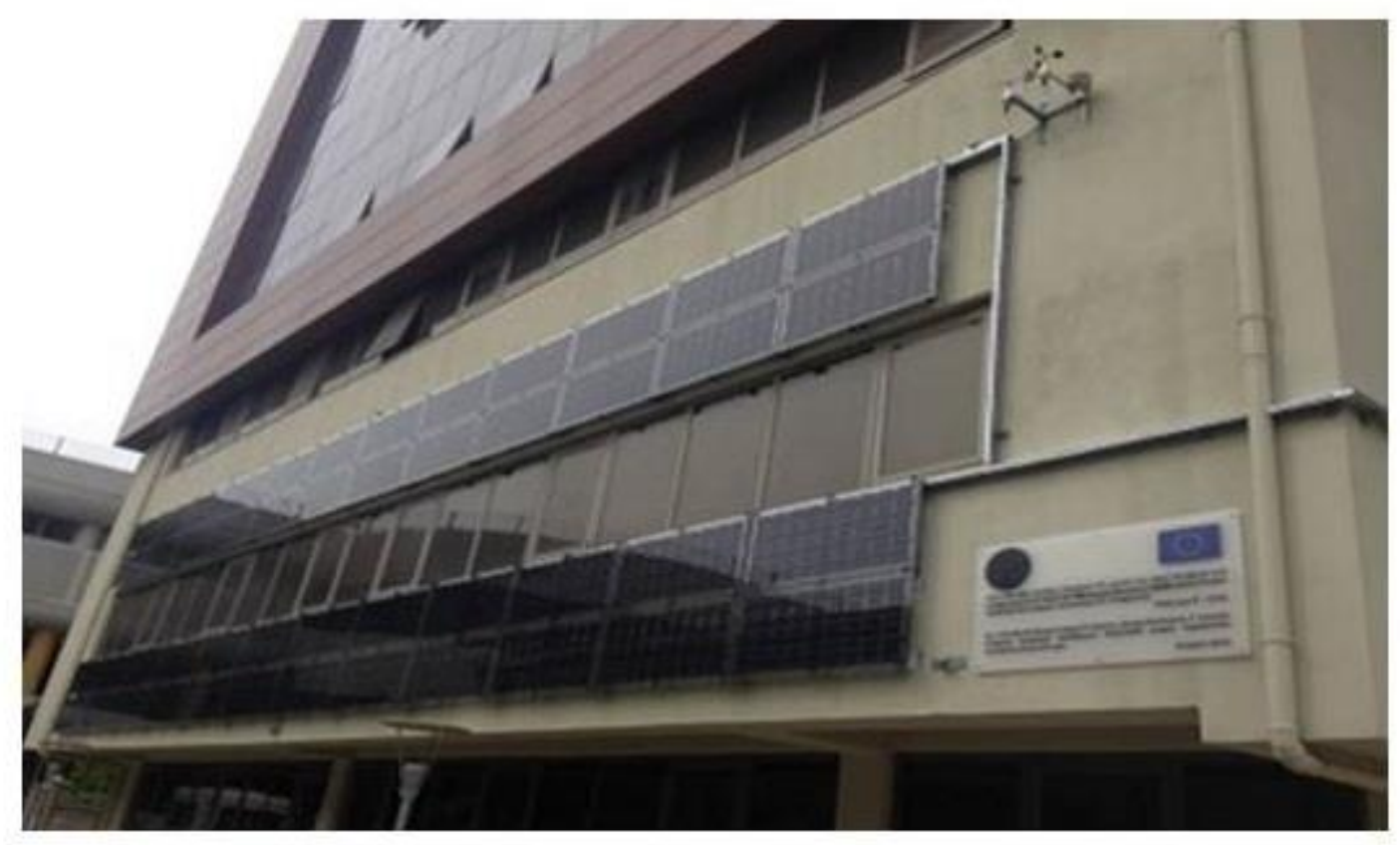

Figure 2. A picture of the BIPV system (Araz et al., 2017). 


\section{BUILDING OPTION 3}

Facade ELEVATION
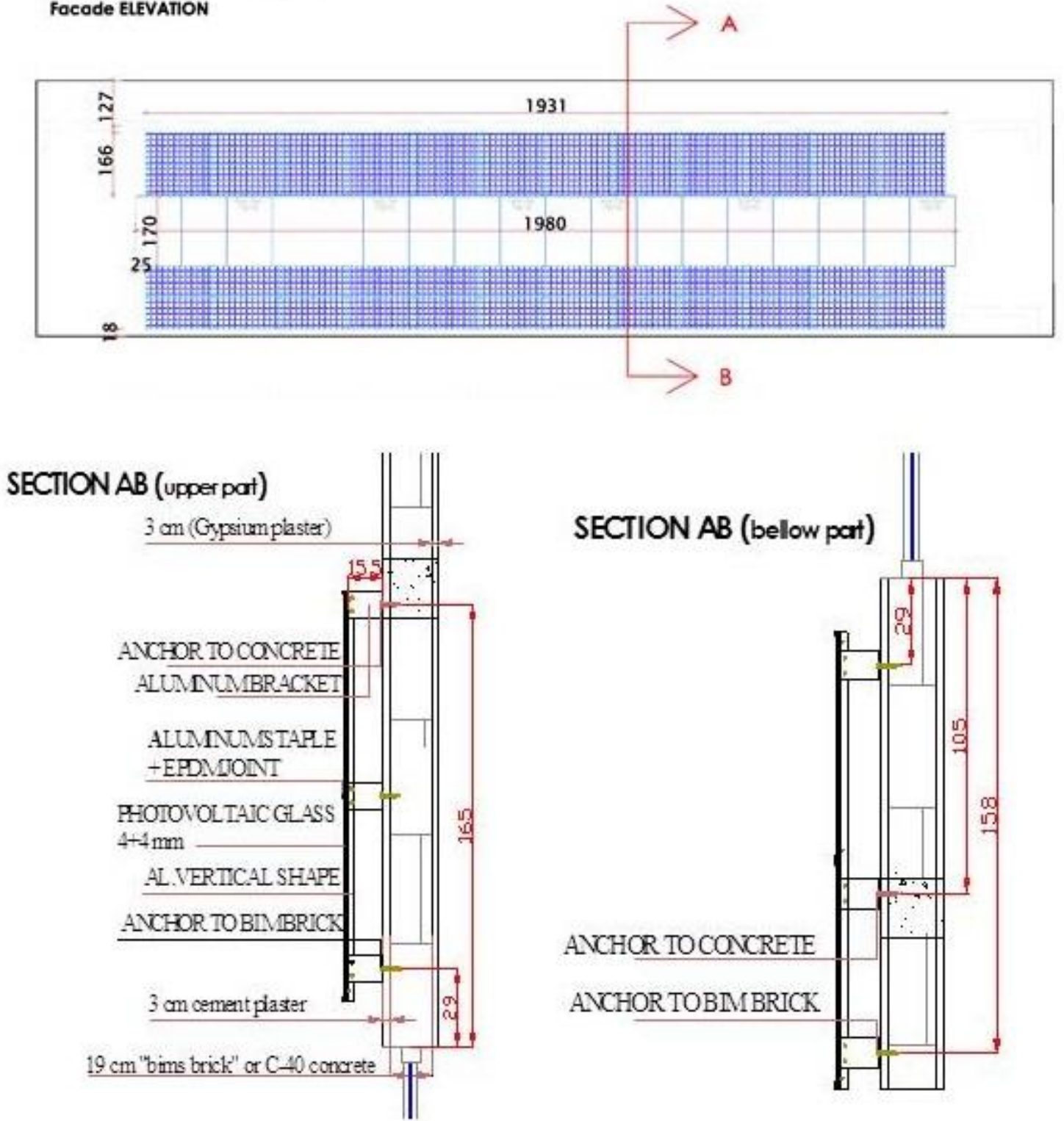

Figure 3. Dimensions and location of PV system together with the cross sections (all dimensions are in $\mathrm{mm})$. 


\section{PV GENERATORONFACADE}

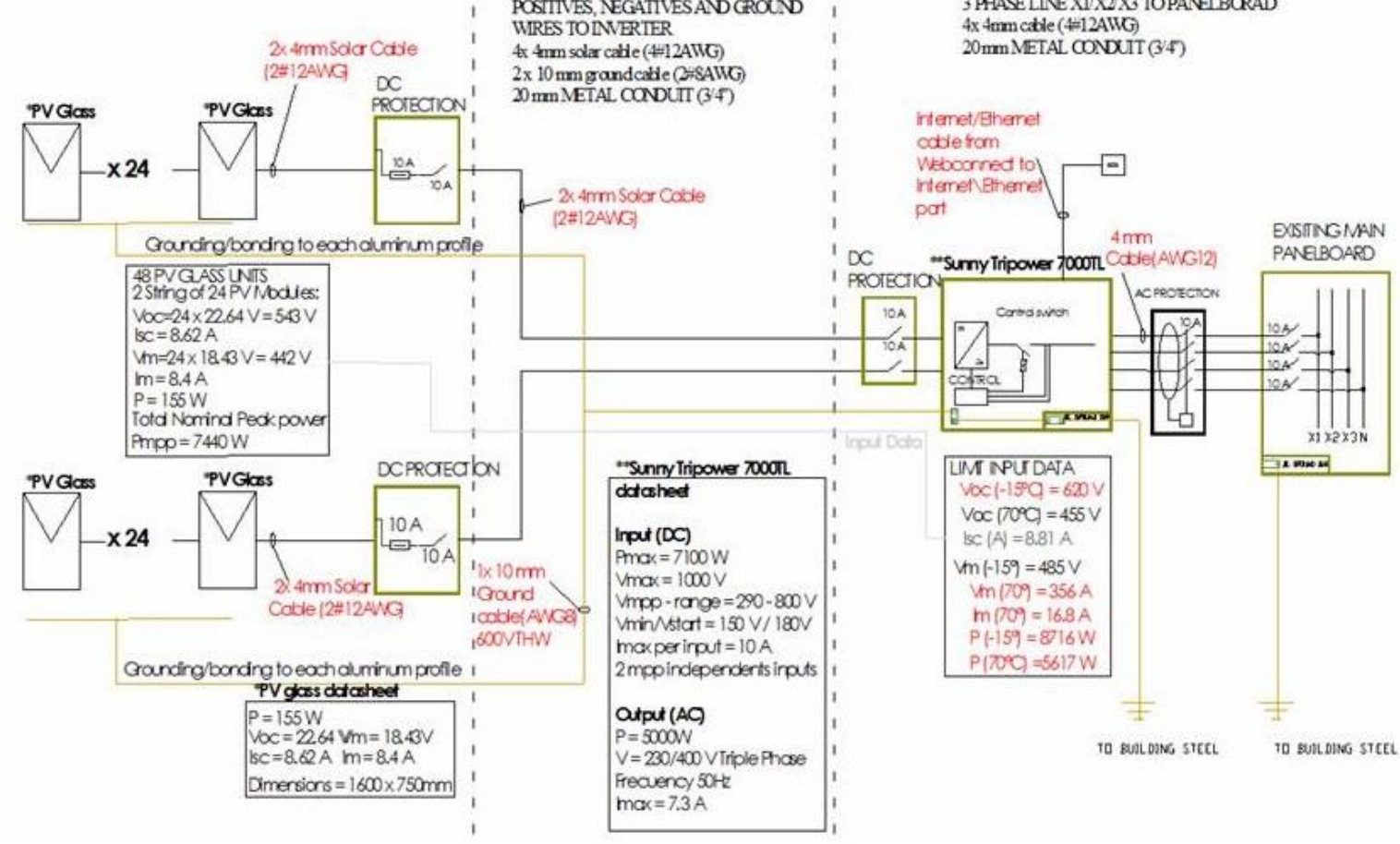

Figure 4. Single line diagram of the system.

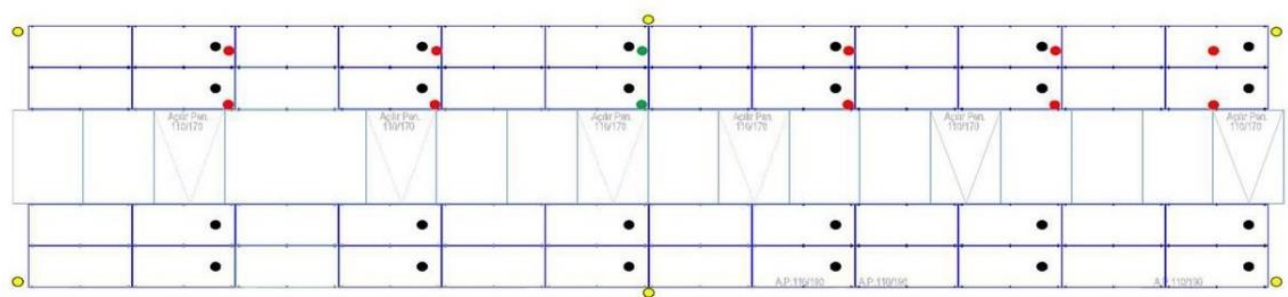

w

Figure 5. P\&ID diagram of the system (Araz et al., 2017).
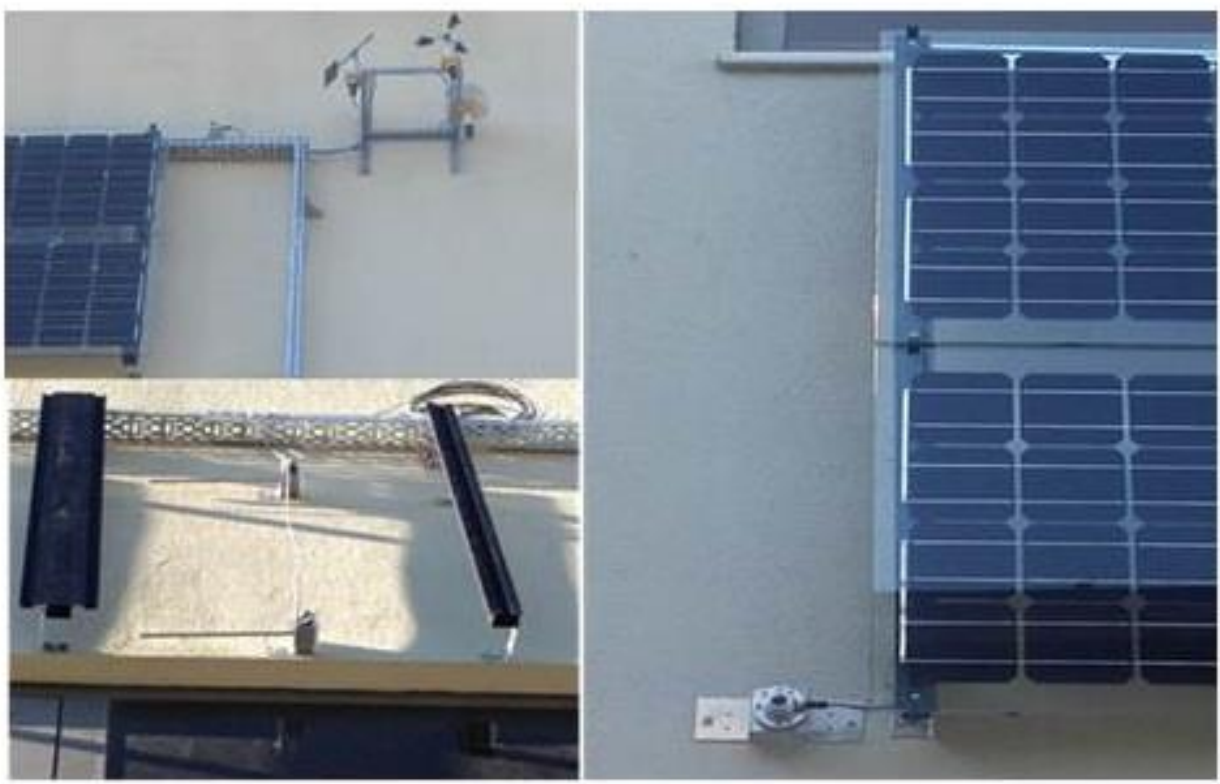
Figure 6. Photos of the measuring devices including weather station and vertical pyranometer.

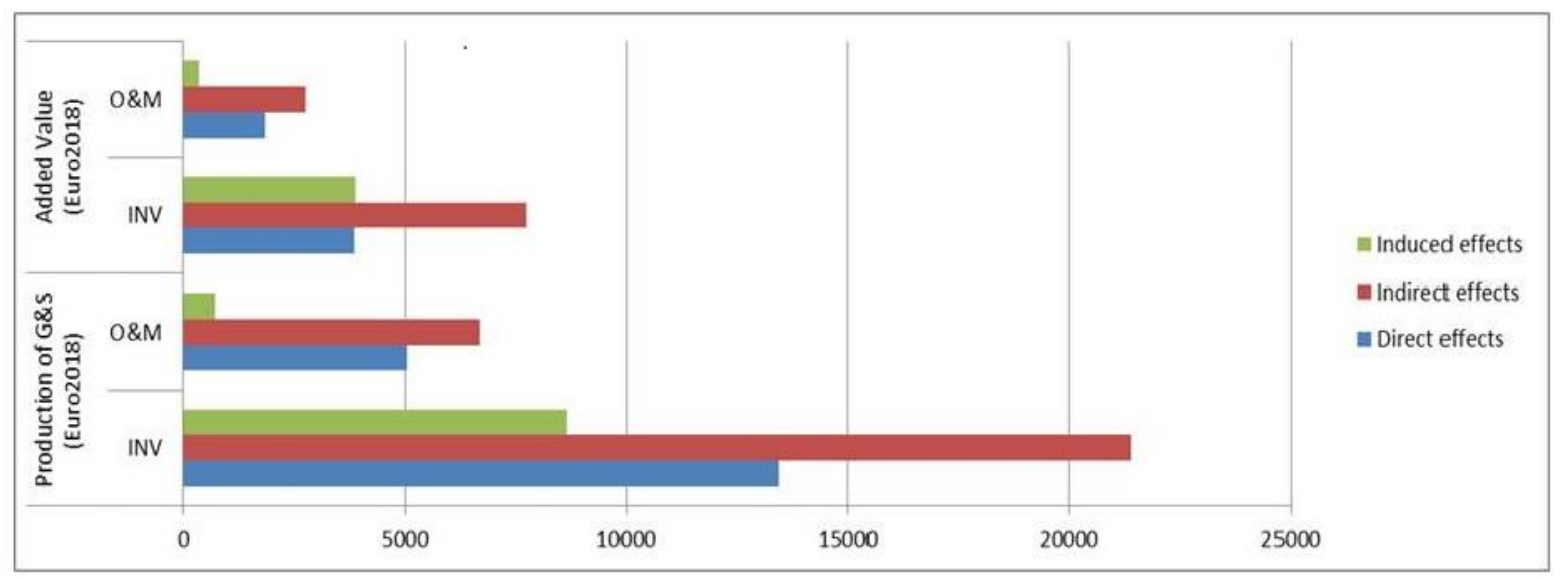

Figure 7. Contribution of direct, indirect and induced effects in the production of G\&S and AV creation $\left(€_{2018}\right)$.

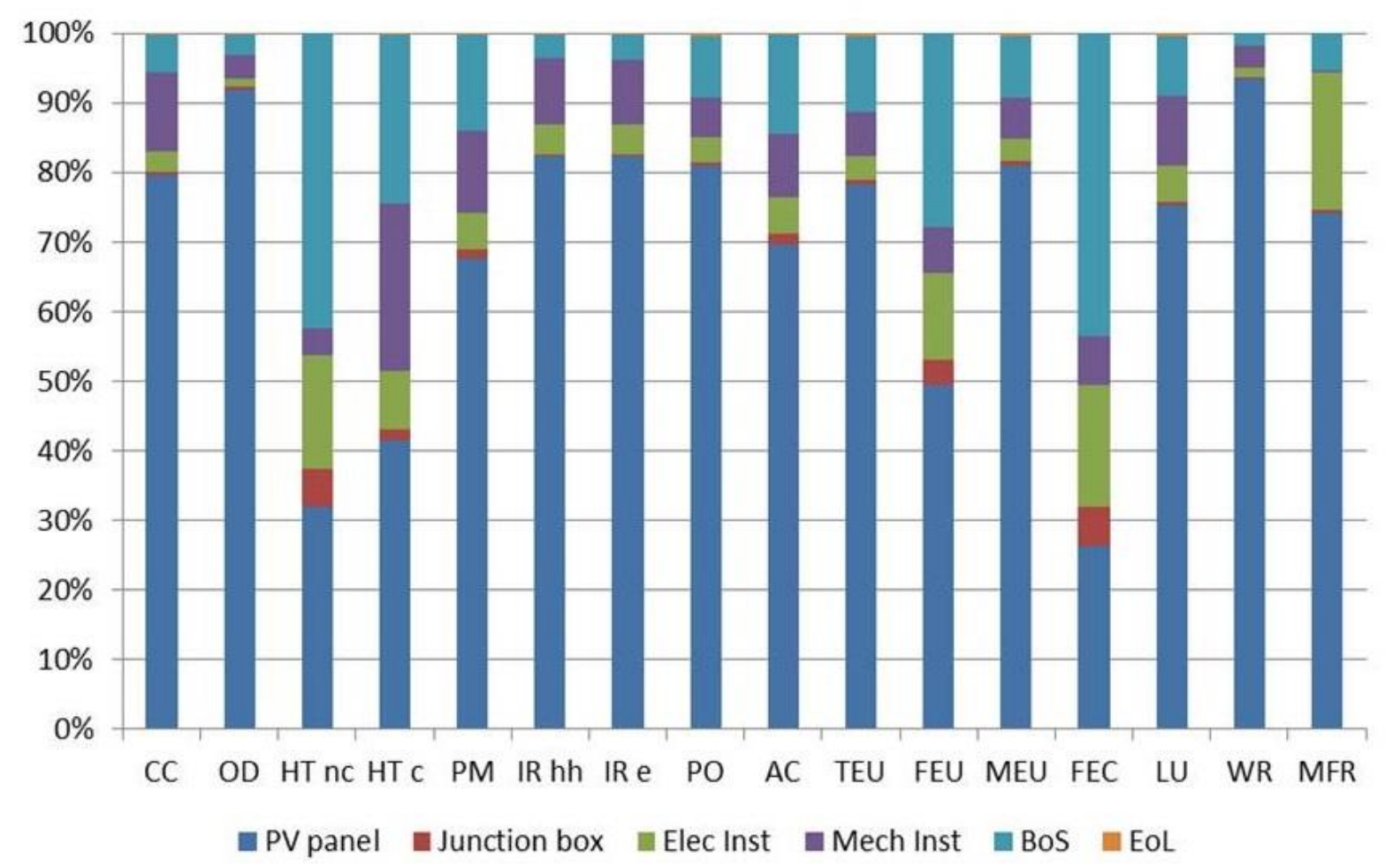

Figure 8. Contribution of each part in the EF of the BIPV. 